think it is worth furtber trial and observation and I hope later to give a further report of these cases. The effects of injection of osmic acid in producing degeneration of tissue are very well marked and, if the ganglion can be destroyed by the means described, relief may be obtained at considerably less risk than is incurred in the operation for its removal.

I am indebted to Dr. Ferguson and to Dr. Fleming, Dr. Howe, Dr. Walker, and Dr. White, my former dressers, for notes of the cases.

Manchester.

\section{AN OUTBREAK OF FOOD POISONING DUE TO EATING BRAWN.}

By GEORGE F. BUCHAN, M.B., CH.B. GLASG., D.P.H. CaNTaB.

ASSISTANT MEDICAL OFFICER OF HEALTH, COUNTY OF ESSEX.

ON Sept. 11th last at a meeting of the Maldon rural district council Dr. J. C. Thresh was informed that many cases of food poisoning had occurred in Tollesbury in that district and in neighbouring parishes in the Lexden and Winstree rural district. The cases occurred five or six days previously. With the consent of Dr. J. W. Cook, medical officer of health of the Lexden and Winstree rural district, Dr. Thresh deputed me to inquire into the nature and cause of the outbreak. 80 cases in all were discovered. The illness was of sudden onset and was characterised by rigors, abdominal pain, vomiting, and diarrhoea of about 24 hours' duration and was followed by great prostration, lasting in some cases for a fortnight. In two cases an itchy petechial eruption confined to the arms and legs appeared a fow days after the initial symptoms, and in one case acute lobar pneumonia set in three days afterwards. There was no ophthalmoplegia, diplopia, or strabismus, and there were no nervous symptoms of central origin. In all these cases pork brawn had been partaken of from one-half to four hours prior to the onset of the illness, and on inquiry it was found that this brawn had been obtained from one source. The pork butcher who made and sold it said that it was prepared in the following manner. The bones, "rhinds" (skin), and eye-pieces (balf the face and bead with eyeballs and brains removed) of five pigs killed 24 hours previously were boiled with water in an iron boiler for from four to six hours and afterwards were put out to cool about 20 yards from the slanghter-house. When the temperature had fallen to about $100^{\circ} \mathrm{F}$. the bones were removed with a large wooden spoon kept for the purpose, the spices (all-spice, pepper, and salt) ${ }^{1}$ were then added, and the brawn was poured into separate dishes containing from four to 16 ounces each and allowed to set. No preservative of any kind was added and the brawn was sold in these dishes on the following day, Sept. 6th. 42 people ate it on that date and 13 were ill, 71 people ate it on the 7th and 65 were ill, while four ate it on the 8th and all were ill. (N.B.-Two people were ill on two dates having partaken of it twice.) A dog got some on the 10th and shortly afterwards was taken "'queer,' lying about and refusing its food, but it was given castor oil and soon recovered. All the patients took but little of the brawn, about an ounce or so, and the symptoms were apparently most severe in those partaking of it on the 7th and 8th. As the pork butcher could not understand why so many cases of illness should have arisen from eating brawn which he had prepared in a similar way for 20 years he retained a portion and this he handed over to me for examination on Sept. 13th. The sample, about four ounces, showed signs of decomposition. A portion was used for examination for toxins and ptomaines and the remainder for bacteriological examination. A search was made for food poisoning organisms in the following manner. An emulsion of scrapings from the outside of the brawn (referred to as A), about 1 gramme to 100 cubic centimetres, was made with sterile water and also a similar emulsion with a portion from the inside (referred to as B). 30 cubic centimetres of emulsion A were put into glucose neutral red broth; fluorescence was produced in 48 hours, and microscopical examination of the liquid showed motile Gramneyative coli-like organisms in large numbers, a few longer Gram-positive bacilli, and some short chains of streptococci.

1 Samples of all these were examined by Dr. Thresh and found to be satisfactory.
Emulsion B treated in a similar way did not give fluorescence in 48 hours, but coli-like organisms were abundant. 20 cubic centimetres of emulsion A cultured anaerobically in sterile milk after heating for 15 mixutes at $80^{\circ} \mathrm{C}$. gave no reaction. 20 cubic centimetres of emulsion B similarly treated brought about slow decomposition of the milk with production of much gas and a putrid odour indicating the presence of the bacillus cadaveris sporogenes. A looplet of each emulsion was next put into MacConkey's glucose broth ${ }^{2}$ and allowed to incubate at $98^{\circ} \mathrm{F}$. for 24 hours when much acid and gas resulted, and plates on Conradi-Drigalski nutrose litmus lactose medium were made from each. Those obtained from emulsion A jielded equal numbers of blue and red colonies, while those from emulsion B gave blue colonies to red in the proportion of 1 to 12 . From these plates several red colonies were selected and were found to produce indol in 24 hours, acid and gas in litmus lactose gelatin, and fluorescence with or without gas production in neutral red saccharose gelatin These results place the red colonies obtained in the coli group. 20 blue colonies were next selected and their action was tested on the following media : broth, lactose, saccharose dulcite and mannite litmus broth with Durham's tubes for noting gas production, and litmus milk. The results obtained gave three classes of bacilli with the following characteristics :-

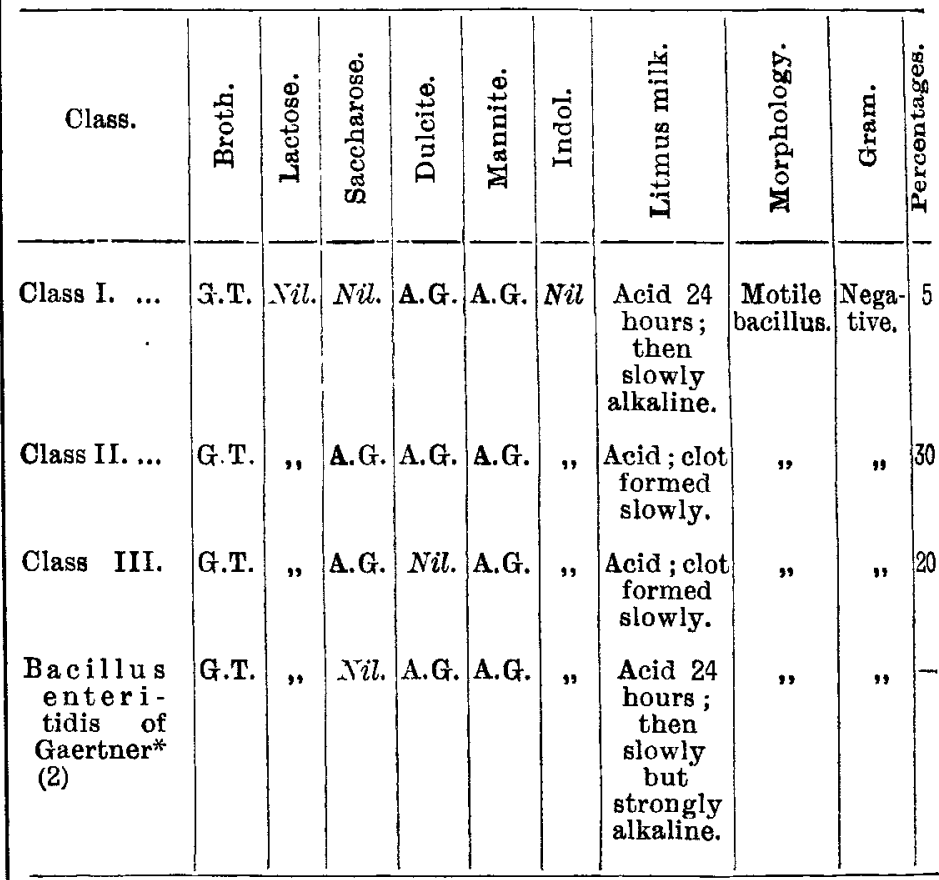

* Put on for purposes of comparison.

G.T. = general turbidity; A.G. = acid and gas. The percentages indicate the proportion in which these organisms were found. The other organisms isolated resembled the coli group in certain essentia details.

One representative of each of the three classes was selected and tested against the sera ${ }^{3}$ of animals immunised against the bacillus enteritidis of Gaertner (limit of agglatination with immunising organism 1 in 1000), bacillus paratyphoid A (Brion and Kayser) , limit of agglutination against immunising organism 1 in 100), and paratyphoid B with the following results :-

\begin{tabular}{|c|c|c|c|c|c|c|}
\hline \multirow[t]{2}{*}{ Class. } & \multicolumn{3}{|c|}{ Gaertner serum. } & \multicolumn{2}{|c|}{$\begin{array}{c}\text { Paratyphoid } \\
\text { A serum } \\
\text { (Brion and Kayser) }\end{array}$} & \multirow{2}{*}{$\begin{array}{c}\text { Para- } \\
\text { ty phoid } \\
\text { B serum. } \\
1 \text { in } 100 .\end{array}$} \\
\hline & 1 in 100 & 1 in 240 . & 1 in 1000. & $\operatorname{lin} 100$ & 1 in 240. & \\
\hline Class I. ... & ++ & + & $?$ & Nil. & Not done & $N i$ \\
\hline Class II. ... & ++ & + & $?$ & $?$ & Nil. & $"$ \\
\hline Class III.... & + & $?$ & Nil. & Nil. & Not done. & $n$ \\
\hline
\end{tabular}

$++=$ complete clumping $t=$ nearly complete but some free bacilli. $?=$ a few clumps with many free bacilli

2 The majority of food poisoning organisms are dulcite fermenters, and by means of primary differential culture in dulcite media th dulcite fermenters are found in increased proportion (A E. Buycott, Journal of Bygiene, 1906, vol. vi., p. 35). A glucose medium was selected as being of more general applicati $n$ for all classes of organisms of intestinal type.

3 For these sera and bacilli I am indebted to Dr. W. G. Savage of Colchestex. The sera were prepared by immunibing rabbits with the oryanisms in question, and were withdrawn frum the rabbits in March, 1907. 
The researches of Durham, ${ }^{4}$ Morgan, ${ }^{5}$ Boycott, ${ }^{\circ}$ and others have proved that bacilli react with homologous but not with heterologous sera. This fact places Classes I. and II. and possibly Class III. as allies of the bacillus enteritidis of Gaertner. Unfortunately the original degrees of agglutina. tion of these sera were not high, and high limits of agglutination with homologons organisms could not therefore be expected. It next became necessary to ascertain to what extent the sera of affected patients reacted with the isolated and closely allied organisms and I obtained the sera of six patients for this purpose. The following table indicates the results obtained :-

\begin{tabular}{|c|c|c|c|c|c|c|c|c|c|c|c|c|c|c|}
\hline \multirow[t]{2}{*}{ Sera. } & \multicolumn{3}{|c|}{$\begin{array}{c}\text { Organism } \\
\text { Class I. }\end{array}$} & \multicolumn{3}{|c|}{$\begin{array}{c}\text { Organism } \\
\text { Class II. }\end{array}$} & \multicolumn{3}{|c|}{$\begin{array}{l}\text { Organism } \\
\text { Class III. }\end{array}$} & \multicolumn{3}{|c|}{$\begin{array}{l}\text { Bacillus } \\
\text { enteritidis } \\
\text { (2) of } \\
\text { Gaertner. }\end{array}$} & \multicolumn{2}{|c|}{ 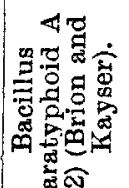 } \\
\hline & $\begin{array}{l}1 \text { in } \\
100\end{array}$ & $\mid \begin{array}{l}1 \text { in } \\
500\end{array}$ & $\left|\begin{array}{ll}1 & \text { in } \\
1000\end{array}\right|$ & $\begin{array}{l}1 \text { in } \\
100\end{array}$ & $\left\{\begin{array}{l}1 \text { in } \\
500\end{array} \mid\right.$ & $\begin{array}{l}1 \text { in } \\
1000\end{array}$ & $\begin{array}{l}1 \text { in } \\
100\end{array}$ & $\left|\begin{array}{l}1 \\
500\end{array}\right|_{1}^{1}$ & & $\begin{array}{l}1 \text { in } \\
100\end{array}$ & $\left|\begin{array}{l}1 \text { in } \\
500\end{array}\right|$ & $\mid \begin{array}{l}1 \text { in } \\
1000\end{array}$ & $\left|\begin{array}{ll}1 & \text { in } \\
100\end{array}\right|$ & \\
\hline D..$^{*}$ & ++ & ++ & + & ++ & ++ & + & + & $?$ & Nil. & ++ & + & Nil. & + & $N i$ \\
\hline M.D. & ++ & + & $|N i l|$. & $+t$ & + & Nil & + & $\mathrm{Nil}$ & ," & + & $?$ & , & Nil & , \\
\hline A.S. & $\begin{array}{l}\text { Not } \\
\text { done }\end{array}$ & + & $"$ & $\begin{array}{l}\text { Not } \\
\text { done }\end{array}$ & + & 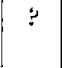 & $\begin{array}{l}\text { Not } \\
\text { done }\end{array}$ & & $"$ & + & ? & $"$ & + & \\
\hline M.S. & " & + & ", & ", & + & ? & + & Nil. & ", & + & $?$ & ", & + & ", \\
\hline G.B. & $"$ & + & ," & " & + & Niti. & + & ", & $"$ & + & $?$ & ", & Nil. & " \\
\hline C.H. & $"$ & + & ", & , & + & ", & + & " " & & + & $?$ & " & & ", \\
\hline
\end{tabular}

* Serum of this patient clumped organisms belonging to Class I. and Class II. in a dilution of 1 in 5000 but not completely.

The laboratory culture of the bacillus typhosus was not agglutinated by any of these sera. Normal serum did not agglutinate any of these organisms.

Here, then, we have groups of organisms isolated from the pork brawn which react with the sera of affected patients and also with the sera of animals immunised against known food poisoning organisms. It seems probable from the sera tests that they are organisms of the enteritidis type and from the cultural reactions as well. Class $[$. seems to be identical with the bacillns enteritidis of Gaertner. Which of them was the exciting cause of the present outbreak became a question of virulence. Dr. J. W. H. Eyre and Dr. W. G. Savage therefore very kindly carried out animal experiments and I am greatly indebted to them for their reports which are as under.

REPoRT BY DR. SAVAGE ON IsOLATEd ORgaNiSMs.

Cultures I., II., and III.-Oct. 7th: Mouse injected subcutaneously with one cubic centimetre of an equal mixture of two-day broth cultures of Nos. I., II., and III. mixed-i.e., about one-third of a cubic centimetre of each injected. Mouse well 8th, 9th, and 10th. 1lth Found to be very ill and in a dying condition. Animal killed. Postmortem examination: Very enlarged dark spleen, and with ljghter coloured (apparently necrotic) areas in the liver. Cultivations from spleen and heart blood showed abundant growth in broth. The latter plated out gave numerous colonies, apparently all alike. A number of these subcultured and all alike and $=$ No. I. Evidently, therefore, No. I. is pathogenic to mice and it is doubtful if Nos. II. and III. are, since not recovered post mortem. I should think No. I. is the cause of the outbreak rather than Nos. II. and III.

Report by Dr. Eyre on Spectuen of Putrid Pork Brawn RECHIED SEPT. 16TH, 1907, FROM DR. THRESH.

1. Number of organisms present per gramme, 273,000,0c0. Organisms present: bacillus coli communis, 10,000,000 per gramme; bacillus paratvphosus type A, 10,000,000: and bacillus enteriditis of Gaertner, 10 000,000. 3. Two mice, each 20 grammes in weight, fed on Sept. 16th, 17th, and 18th with portions of the putrid brawn (no other food being administered). Pemained unaffected. 4. Rabbit, 950 grammes in weight, received one cubic centimetre of the thick emulsion of brawn mass after extraction with alcohol, \&c. (received from Dr. Thresh Sept. 18th), subcutaneously. No apparent effect. Animal remains well.

The apparent discrepancy between the results of the feeding experiments by Dr. Eyre and the injection of

H. E. Durham : An address on the Present Knowledge of Out breaks due to Meat Poisoning, Brit. Med. Jour., 1898, vol. ii., p. 1797. $5 \mathrm{H}$. de R. Morgan: Some Observations upon the Micro-organisms of p. 1257 .

${ }^{6}$ A. E. Boycott: Observations on the Bacteriology of Paratyphoid Fever and on the Reactions of Typhoid and Paratyphoid Sera, Journal of Hygiene, 1906, vol. vi., p. 33. isolated organisms by Dr. Savage finds a parallel in experiments by Professor S. Delépine in connexion with the Manchester outbreak of diarrboea due to consumption of milk in November, 1894. ${ }^{7}$ He explained the fact that large doses of this milk given to two guinea-pigs and two young rats did not produce any distinct illness by the diminution in virulence of the milk due to acid fermentation. In the present case acid fermentation may have played a part in diminishing the virulence of the pathogenic organisms, but it is probable that the putrid state of the brawn when delivered at Dr. Eyre's laboratory 12 days after it was made did not tempt the mice to partake of it in sufficient quantity to cause illness, especially when only 5 per cent. of the blue colonies (or a little. more than 1 per cent. of the total number of organisms), even after enrichment by culturing in MacConkey's glucose broth, were pathogenic. It seems clear, therefore, that the pathogenic organisms which had caused such severe symptoms in so many people had in large proportion died out before the analysis was begun ten days after the brawn was prepared.

This outbreak presents many features of interest. $32 \cdot 3$ per cent. of the persons eating the brawn 24 hours after its preparation, $91 \cdot 5$ per cent. of those eating it 48 hours, and 100 per cent. ${ }^{8}$ of those eating it 72 hours afterwards were ill. Symptoms began in every case in from half an hour to four hours after ingestion. These facts prove that the germs multiplied in the brawn, that the symptoms were the result of the excessive number ingested, and that the outbreak was due to an actual infection by living bacilli. Dr. Thresh on testing for ptomaines by the Stas-Otto method failed to detect their presence, and detail No. 4 of Dr. Eyre's report shows that poisonous toxins were absent. The rapidity with which the pathogenic bacteria died out is illustrated by the results of the bacteriological examinations begun ten days after the brawn was prepared, by the feeding experiments conducted 12 days afterwards, and also by the comparatively slight symptoms exhibited by the dog which swallowed a large portion of the then putrefying brawn on the fifth day after its preparation.

The important question from the public health point of view is how did the brawn become infected? Only those who ate the brawn were ill. There was no illness of any kind amongst those eating the fresh pork or the sansages sold by the same butcher on the same day from the same animals, and inquiries failed to show that there had been anything amiss with the pigs prior to their being killed. I have described already the method of preparation of the brawn and pointed out that it was pat out to cool 20 yards from the slaughter-house where the animals were killed. The researches of Morgan ${ }^{10}$ show that organisms of the enteritidis type are obtained with great frequency from the fæces and surface of the intestinal mucous membrane of pigs and other animals. Intestinal organisms of every type abounded in the specimen of pork brawn submitted to examination and nothing more likely can be imagined than that it became infected from the intestines of the recently killed pigs. The infection must have reached the brawn during the cooling stage and before it was poured into separate dishes as all the brawn gave rise to symptoms. Inasmuch, too, as the Drigalski plates from both inside and outside of the brawn showed the presence of intestinal organisms in approximately equal numbers it is obvious that these must have reached it before it was poured into the moulds. Otherwise the interior of the brawn would have contained far fewer organisms. What the particular carrier of infection was it is more difficult to say. The common house-fly certainly carries infection broadcast, as has been demonstrated by numerous observers, ${ }^{11}$ and the proximity of the slanghter-house to the cooling place gave abundant opportunities for this agent during the hottest period of this year to bring about inoculation of the brawn. At the same time, it must not be forgotten that the slaughter-house was a private one and the same persons were engaged in slaughtering the pigs and preparing the brawn for the market. The outbreak appears to add another to the list of those due to the use of pig meat and to the presence of

$7 \mathrm{~S}$. Delépine: The Bearing of Outbreaks of Food Poisoning upon the Ftiology of Epidemic Diarrhcea, Transactions of the Epidemiological Society of London, December, 1902.

Only four altogether and they were young children. 1906, p. 323 .

10 H. de R. Morgan : Ibid. 11 R. M. Buchanan: The Carriage of Infection by Flies, THE LATCET 
the bacillus enteritidis of Gaertner, and although it is doubtful whether any amount of inspection would have prevented it, it emphasises the necessity for regulations and for inspection of premises and of the conditions under which such food is prepared. The water.supply to the parish and premises is limited in amount and not over excellent in quality. It is not such as could be regarded as adequate and suitable for a place of this character. For permission to publish this paper and for much help and advice during its construction $I$ have to express my indebtedness to $\mathrm{Dr}$. Thresh, in whose laboratory the bacteriological work was carried out.

Dartford.

\section{ACUTE PULMONARY CEDEMA.}

\section{By LEONARD WILLIAMS, M.D. GLASG.,} M.R C.P. LoND.,

PHYSICIAN TO THE FRENCH HOSPITAL; ASSISTANT PHYSICIAN 'TO THE METROPOLITAN HOSPITAL.

ON Nov. 1st, 1907, a man, aged 50 years, came to the outpatient room of the Metropolitan Hospital to report himself. He had left the hospital a fortnight before, having been an in-patient with aortic regurgitation under the care of Dr. Hugh Thursfield. I examined him on the couch in the side room and found that his heart was enlarged in all directions, that he had a see-saw murmur at the aortic base, tortuous radial arteries, and a systolic blood pressure of 165 millimetres of mercury. There were some very fine moist râles at both pulmonary bases behind. So far from seeming distressed he appeared to be remarkably cheerful and loquacious. Having finished my examination I returned to the main room. Very soon afterwards I heard the patient cry out as if with sudden pain and I immediately went to him. I found him leaning against the side of the couch clutching at his throat; to my inquiry he replied that when he got off the couch he could not "tetch his breath." His face was cyanosed and moist with perspiration; he was very breathless and wore a look of great anxiety. Mr. Kendrew, the junior house physician, then joined me, and we laid the patient on his back and sent for some oxygen. The cyanosis, the dyspnoea, and the anxiety all rapidly increased, but instead of remaining immobile, as in angina pectoris, the patient rolled about, clutched at his throat, shouted ont, and shortly became unconscious. A quantity of froth (estimated at rather more than a pint) now began to issue continuously from his mouth and nose. It was not unlike the froth of beer, from which it differed in being finer and thinner. In spite of oxygen inhalation, of strychnine subcutaneously, and artificial respiration hedied, well within a quarter of an hour from the commencement of the attack. Death was certainly not due to syncope, for his heart continued to beat strongly after he was apparently suffocated. Owing to difficulties with the relatives the necropsy did not take place until Nov, $4 \mathrm{sh}$, that is, three full days after death. The examination revealed no new fact. The heart was enlarged, especially the left ventricle, the aorta, including the aortic valves, was atheromatous, though not very markedly so. The coronary arteries were patent and undegenerated. The lungs, though emphysematous and slightly congested at their bases, were substantially normal. The kidneys were practically unaffected. T'he brain was normal. What was the cause of death?

For an answer to this question the diligent seeker after truth will appeal to the English text-books in vain. Alone among those which I have consulted, and they are many, Kingston Fowler and Rickman Godlee ${ }^{1}$ refer specifically, though briefly, to the subject. Nor are the German writers more helpful. Sticker, the author of an otherwise excellent and exhaustive article in Nothnagel (Specielle Pathologie und Therapie, Band xiv.) on the subject of pulmonary œdema, although he quotes, to condemn it, Cohnheim's saying, "Die Menschen sterben nicht weil sie Lungenödem bekommen, sondern sie bekommen Lungenü lem weil sie im Begriffe sind za sterben," makes no mention of an acute form. It is only the French text-books which throw any light on the question. In vol. $i$. of the third edition of his "Maladies du Coeur et de l'Aorte," p. 300, Huchard, in a discussion of the matter which extends over several pages, quotes the following from de la Harpe ${ }^{2}$ as the description of a typical case of hyperacute celema of the lungs (forme suraiguë ou foudroyante).

Un malade est réveillé en sursaut pendant la nuit. Il saute hors de son lit, traverse la chambre, s'assied sur une chaise, râlant: quelque instants après, il etait mort, et une houppe de mousse blanche sortait abondamment de la bouche et des narines.

In the matter of information to be obtained from periodical literature the English reader is more fortunate; for not only is there an excellent lecture by Dr. J. Lindsay Steven of Glasgow, giving the details of two cases, in THE LANCET of Jan. 11th, 1902, p. 73, which evoked an equally interesting and eminently readable paper by $\mathrm{Mr}$. Thomas Lissaman of Bolton-le-Moors in THE LANCET of Feb. 8th of the same year, p. 366, but there is a very instructive article by $\mathrm{Dr}$. H. M. Hewlett in the Intercolonial Medical Journal of 1903 and, finally, in the American Journal of the Medical Soiences of January, 1907, a most exhaustive review of the whole subject with full bibliography from the pen of Professor David Riesman of Philadelphia. These, however, are not to every one's hand, and on 3 feels that the gist of the information which they contain ought to be more easily accessible. Having regard to the fact that in France the existence of the condition has been recognised and its meaning discussed practically since the days of Laennec (1781-1826), and vigorously since Andral wrote on the subject in 1837, it is surely high time that the matter were adequately noticed in the text-books in this country. Of the 44 separate references given by Riesman, 28 are in French, nine are in English, and seven are in German. The silence of our textbooks on the subject is remarked upon and deplored by all the English writers, notably by Hewlett, and Riesman pleads strongly in favour of the condition being given a separate place in the standard works.

To return to the case which I have just described. Clinically, there seems to be no doubt that it was a typical example of hyperacute or "foudroyant" pulmonary cdema. The dramatically sudden onset, the lividity, the dyspncea, the physical and mental distress, the foam issuing from the mouth and nose, and the appallingly rapid termination suffice to place it unmistakeably in the same category as those described by others. It is interesting to note that most of the recorded cases have occurred at night-i.e., when the patient was recumbent, and that mine occurred after the patient had been lying on the couch. This looks as if position might have some connexion with the provoking cause, a suggestion which is borne out by the events which always preceded the attacks in Hewlett's Case $1 .^{3}$ My patient had aortic disease. The ascending aorta was atheromatous and the cusps were sufficiently involvad to produce during life a see-saw murmur which was unmistakable. He also had tortuous radial arteries. That there is some definite relation. ship between the occurrence of acute pulmonary odema and cardio-vascular disorders is a matter upon which most of the writers on the subject are agreed. Huchard goes so far as to say that aortitis and peri-aortitis is the only cause, but from the records of other authors this is evidently far too restricted a view of the matter. Clifford Allbutt ${ }^{4}$ lays stress upon the probable coincident responsibility of general arteriosclerosis, and many have associated the condition with that form of arteriosclerosis which is commonly called granular kidney. Moreover, Kingston Fowler and others describe the seizures as occasionally taking place in acute affections such as typhoid fever, in which the cardio-vascular apparatus may be assumed to have been structurally normal. Nevertheless, it seems desirable to emphasise the point that acute pulmonary œdema is one of the ways in which people, especially those suffering from cardio-vascular complaints, may meet with sudden death. The condition may indeed in this respect be held to rank in importance, though not in frequency, with angina pectoris. As in angina pectoris, there may be recurrent attacks; and, as in angina pectoris, the first attack may be the last.

A small proportion only of the recorded cases contain an account of post-mortem findings. In the majority of those which do, the lungs were definitely œedematous, and in some, the trachea and larger tubes were filled with the characteristic froth, which one French writer describes as "une écume d'un blanc pur, semblable à des oeufs battus en mousse" ${ }^{5}$; Huchard says that it may be "de coloration rosée, d'apparence saumonés," and Riesman that "it is often

Revue Médicale de la Suisse Romande, 1881, p. $322 . \quad 3$ Page 612

4 The Cavendish Lecture, The LANCET, J uly 18th, 1903, p. 139. 